\title{
DAMPAK KONSUMERISME BUDAYA KOREA (KPOP) DI KALANGAN MAHASISWA FAKULTAS ILMU SOSIAL UNIVERSITAS NEGERI MALANG
}

\author{
Dzakkiyah Nisrina, Incka Aprillia Widodo, Indah Bunga Larassari, \& Fikri Rahmaji \\ Pendidikan Sosiologi Fakultas Ilmu Sosial, Universitas Negeri Malang \\ Jalan Semarang No 5, Malang \\ Email: Dzakiyyahnis.firdaus@gmail.com
}

Submitted: 2019-08-05

Accepted: 2020-01-31

Published: 2020-02-01

\begin{tabular}{ll}
\hline Keywords: & Abstract \\
\hline Consumerism, & The rapid flow of globlalization makes foreign cultures enter \\
Effect, Korean Pop & through several media platforms supported by easy internet \\
Culture & access. Including KPOP culture that entered and spread \\
& among teenagers, especially students. KPOP culture is often \\
& associated with consumerism because of the level of \\
& spending money on KPOP stuff on a regular basis in a \\
& certain period of time. The purpose of this study was to \\
& determine the impact of KPOP cultural phenomena on \\
& economic, social and cultural aspects. The method in this \\
& study was a qualitative method with a descriptive approach. \\
& The data collection technique was done by conducting \\
& observations and interviews. Data analysis techniques was \\
& conducted through several stages, namely: Data reduction, \\
& categorization/grouping, data process, data analysis. The \\
& results of this study indicated that Korean pop culture was \\
& so persuasive that it caused changes in people's lives which \\
are unwittingly moved by the capitalists
\end{tabular}

Konsumerisme, Pesatnya arus globalisasi membuat budaya asing masuk Efek, Budaya Pop melalui beberapa platform media yang didukung oleh akses Korea internet yang mudah. Termasuk budaya KPOP yang masuk dan menyebar di kalangan remaja, terutama pelajar. Budaya KPOP sering dikaitkan dengan konsumerisme karena tingkat pengeluaran uang untuk barang-barang KPOP secara teratur dalam periode waktu tertentu. Tujuan dari penelitian ini adalah untuk mengetahui dampak fenomena budaya KPOP pada aspek ekonomi, sosial dan budaya. Metode dalam penelitian ini adalah metode kualitatif dengan pendekatan deskriptif. Teknik pengumpulan data dilakukan dengan melakukan observasi dan wawancara. Teknik analisis data dilakukan melalui beberapa tahapan, yaitu; reduksi data, kategorisasi atau 
pengelompokan, proses data, dan analisis data. Hasil penelitian ini menunjukkan bahwa budaya pop Korea begitu persuasif sehingga menyebabkan perubahan dalam kehidupan masyarakat yang tanpa disadari tergerak oleh kaum kapitalis.

\section{PENDAHULUAN}

Budaya merupakan bagian dari suatu masyarakat yang eksistensinya tidak dapat dipisahkan. Namun, seiring dengan perkembangan yang terjadi, budaya menjadi bersifat dinamis dan mengikuti perkembangan zaman. Salah satu contohnya adalah budaya populer yang biasa disebut dengan budaya pop. Budaya pop sering dikenal dengan budaya massa yang memiliki maksud budaya yang muncul dan "booming" yang selalu ada di setiap generasi atau massa. Menurut Burton (dalam Ilham, 2017) budaya populer didominasi oleh produksi dan konsumsi barang-barang material dan bukan oleh seni-seni sejati, manakala penciptaannya didorong oleh motif laba. Adapun Ibrahim (dalam Ilham, 2017) berpendapat bahwa budaya populer yang disokong industri budaya telah mengkonstruksi masyarakat yang tidak sekadar berlandaskan konsumsi, tetapi juga menjadikan artefak budaya sebagai produk industri dan sudah tentunya komoditi. Salah satu jenis budaya populer adalah budaya Korean Pop atau yang biasa dikenal dengan Kpop.

Awal mula masuknya budaya K-pop dipelopori oleh munculnya drama Korea pada tahun 2000-an yaitu Endless Love yang ceritanya masih melekat sampai saat ini. Selanjutnya, budaya itu juga didukung oleh munculnya boyband, girlband, dan sejumlah penyanyi lainnya, seperti Bigbang, Rain, BoA, dan masih banyak lagi. Ketika memasuki tahun 2011, K-pop mulai merambah beberapa negara di Eropa dan Asia termasuk negara Indonesia.

Masifnya K-pop di Indonesia dimulai dengan lagu girlband Wondergirl yang berjudul Nobody yang dirilis pada 22 September 2008. Banyak remaja pada saat itu mulai terjun ke dunia $K$-pop dan mulai fanatik dengan hal-hal berbau $K$-pop. Fanatik ini ditandai dengan remaja Indonesia yang mulai menggunakan aksesoris seperti kaos, tas, topi, poster, dan masih banyak lagi. drama Korea juga memiliki peran dalam berkembangnya budaya K-pop di Indonesia. Salah satu drama yang terkenal di tahun 2008 yaitu Boys Before Flower. Hal itu menambah minat remaja Indonesia terhadap budaya Korea. Dalam hal ini industri hiburan di Korea mulai menjual budayanya untuk mendapatkan suatu keuntungan dan tanpa disadari mengakibatkan budaya konsumerisme di kalangan remaja dan pemuda di Indonesia. Namun, budaya $K$-pop tidak serta merta bertahan begitu saja, budaya $K$-pop pernah mengalami kemunduran minat dari masyarakat Indonesia, tetapi kini budaya $K$-pop kembali masif beredar.

Di era modern seperti sekarang ini pecinta K-pop mulai bertambah dan merupakan masalah tersendiri bagi negara dan diri sendiri. Permasalahan pertama yang timbul adalah lunturnya kecintaan terhadap produk-produk dalam negeri, kemudian akan muncul rasa kurang peduli terhadap peristiwa di negara ini, dan sebagaimana peran pemerintah harus menangani dampak yang ditimbulkan dengan melakukan sosialisasi atau internalisasi budaya dalam negeri. Selain itu, permasalahan yang terjadi pada diri sendiri adalah terciptanya suatu perilaku konsumerisme, yakni membeli barang berbau K-pop seperti aksesoris, CD album, photo card, poster, dan lain sebagainya yang hanya berdasarkan keinginan bukan pada kebutuhan. Remaja menjadi kurang bersosialisasi dengan lingkungan sekitar terutama dengan orang yang tidak sehobi dengannya. Hal ini masih terjadi pada remaja dengan rentan umur 19-21 
tahun yang pada hakikatnya sudah melihat kehidupan secara realistis, mulai menentukan jalan hidup mereka dan mulai tampak passionnya. Dari hal ini dapat dilihat bahwa pengaruh budaya $K$-pop, lingkungan di sekitar kita mulai menggeser budaya lokal. Dapat diringkas bahwa budaya $K$-pop sudah mulai menggeser budaya lokal dan memiliki beberapa dampak dalam perubahan sosial, budaya, dan ekonomi.

Dalam artikel "Dampak Modernitas K-pop pada Gaya Hidup Siswi di Sekolah Berbasis Pesantren", oleh Sholihah dan Sudrajat (2019) dijelaskan mengenai budaya K-pop yang sangat jauh berbeda dengan budaya islam berpengaruh besar terhadap siswa pesantren dapat dilhat dari 3 dimensi, yaitu aktivitas, minat, dan opini. Bila dilihat dari dimensi aktivitas, penggemar K-pop dari kalangan siswa pesantren tersebut kerap membelanjakan produk yang terkait dengan K-pop. Pada minat, siswi $K$ popers hanya menyukai dan memprioritaskan hal-hal yang berkaitan dengan K-pop. Pada opini, siswi K-popers berpendapat bahawa K-pop memberikan dampak positif dan negatif. Intensitas konsumsi yang tinggi terhadap K-pop juga berdampak pada berkurangnya konsentrasi siswi pada saat pembelajaran IPS sehingga pendidikan karakter pada pembelajaran IPS tidak tersampaikan dengan baik. Adapun dalam jurnal "Pengaruh Budaya Korea (Kpop) Terhadap Remaja di Kota Cirebon", oleh Ida Ri"aen dkk. dijabarkan mengenai budaya K-pop telah mewabah ke masyarakat di Indonesia salah satunya kota Cirebon. Kpop tidak hanya diartikan sebagai soal musik, tetapi lebih terasosiasikan terhadap semua budaya asal Korea Selatan. Adanya komunitas pecinta K-pop, Dance Cover hingga kedai makan korea, didapati beberapa remaja yang sejatinya menganggap budaya lokal dan nasional lebih mereka kenal. Namun, mereka juga tidak ingin ketinggalan dengan perkembangan budaya Kpop sebagai penggemar. Mereka beranggapan mengikuti perkembangan tersebut adalah sejalan dengan modernitas yang sedang marak.

Dalam jurnal yang berjudul "Perilaku Konsumtif Peserta Didik Penggemar Kpop di SMA Negeri 4 Surakarta", penelitian Wulandari, dkk. (2018), dijabarkan mengenai aktivitas sosial dan tindakan yang dilakukan oleh penggemar K-pop khususnya peserta didik di SMA Negeri 4 Surakarta antara lain meliputi aktivitas fisik yang berupa menonton konser, bergabung dengan komunitas, dan mengunjungi tempat yang memiliki nuanasa Korea dan aktivitas non-fisik yang meliputi menonton dan men-download K-Drama dan MV, serta stalking berita K-Pop dan K-Drama. Selain itu, perilaku konsumtif yang dilakukan oleh penggemar K-pop di kalangan peserta didik SMA Negeri 4 Surakarta meliputi membeli album K-pop dalam jumlah yang banyak, membeli kpopstuff, serta seperti mendatangi restoran yang bernuansa Korea dengan harga yang relatif mahal.

Budaya konsumsi muncul akibat dari kegiatan kapitalisme. Budaya konsumtif ini lahir akibat dari kegiatan kapitalisme. Konsumsi membuat manusia tidak mencari kebahagiaan, tidak berusaha mendapatkan persamaan dan tidak adanya intensitas untuk melakukan homogenisasi-manusia justru melakukan diferensiasi (perbedaan) yang menjadi acuan dalam gaya hidup dan nilai, bukan kebutuhan ekonomi (dalam Pawanti, 2013:02). Adapun faktor terbentuknya gaya hidup pada masyarakat konsumeris menurut Parwanti ada beberapa hal: (a) Terjadinya sejumlah besar dan meningkat secara konstan berbagai jenis barang; (b) Kecendurungan semakin bertambahnya pertukaran dan interaksi manusia yang dimungkinkan melalui pasar; dan (c) Peningkatan berbagai bentuk kegiatan belanja mulai dari pemesanan lewat pos dan lain-lain. Selain itu, pada era modern ini perkembangan teknologi seperti internet memberikan kemudahan dalam berbelanja yang ditawarkan melalui sistem online. (d) Semakin pentingnya pengemasan dan promosi dalam pembuatan, tampilan, dan 
pembelian barang-barang konsumen. (e) Gencarnya iklan-iklan di media yang menawarkan sejumlah produksi-produksi kepada masyarakat. (f) Peningkatan penekanan pada gaya, desain, dan penampilan barang-barang.

Baudrillard memandang objek konsumsi sebagai sesuatu "yang diorganisisasi oleh tatanan produksi" atau dalam artian lain, kenyataannya kebutuhan dam konsumsi adalah perluasan kekuasaan produktif yang diorganisasi. Menurutnya, dalam kegiatan konsumsi hubungan antara manusia dengan objek konsumsi hubungan manusia dengan dirinya sendiri dipalsukan, dikelabui, dan dimanipulasi. Manusia hanya melihat kebutuhan bukanlah apa-apa yang diambil satu persatu, yang hanya satu sistem kebutuhan atau lebih tepat bahwa kebutuhan-kebutuhan sama sekali bukanlah bentuk yang lebih maju dari sistematisasi rasional dari kekuatan produktif pada tingkat individu, ketika "konsumsi" menggantikan logika dan keperluan dengan produksi. Martono (2016:95). Dari permasalahan tersebut, rumusan masalah dalam penelitian ini adalah bagaimana dampak dari fenomena konsumerisme budaya Kpop di kalangan Mahasiswa Fakultas Ilmu Sosial Universitas Negeri Malang.

\section{METODE PENELITIAN}

Metode penelitian yang digunakan dalam penelitian ini adalah metode kualitatif. Metode penelitian ini menggunakan pendekatan secara deskriptif. Teknik pengumpulan data yang digunakan dalam penelitian ini adalah observasi dan wawancara. Selain itu, dalam menentukan narasumber atau informan memiliki kriteria tertentu yang bersifat ilmiah. Kriteria informan atau narasumber antara lain: remaja berumur 19 sampai 21 tahun, berstatus mahasiswa, melakukan rutinitas pembelian $K$ popstuff dalam kurun waktu dua sampai tiga bulan Pengambilan narasumber atau informan dengan rentan usia 19-21 tahun didasarkan pada perkembangan psikologisnya menurut Havighurst (1998) dalam Kusmiran (2014) yang menyatakan b ahwa individu dalam usia tersebut mencapai relasi yang baru dan lebih matang dengan teman sebaya, baik sejenis maupun lawan jenis.

Berstatus mahasiswa dikarenakan cakupan yang banyak, luas,heterogen, mampu menjawab dengan rasional dan akademis, serta melakukan belanja $K$-popstuff dengan kurun waktu dua hingga tiga bulan disebabkan akan menunjukan suatu intensitas kegiatan konsumtif. Berdasarkan kriteria informan yang ditentukan tersebut, subjek penelitian ini berjumlah tiga informan yang merupakan Mahasiswa Fakultas Ilmu Sosial Universitas Negeri Malang. Analisis data dilaksanakan dalam beberapa tahap, yakni reduksi data, menggunakan kategorisasi atau pengelompokkan, mengolah data, menganalisis data

\section{HASIL DAN PEMBAHASAN}

\section{Remaja dan Dunia Kpop}

Remaja merupakan masa-masa eseorang masih mudah terpengaruh oleh lingkungan sekitar serta masih memiliki sifat yang labil. Di rentan usia ini mereka akan mencari identitas diri. Definisi remaja (adolescence) menurut organisasi kesehatan dunia (WHO) tahun 2007 adalah periode usia antara 10 sampai 19 tahun. Adapun Perserikatan Bangsa Bangsa (PBB) menyebut kaum muda (youth) untuk usia antara 15 sampai 24 tahun. Pada masa perkembangannya secara psikologis, remaja merupakan masa yang di dalamnya individu mengalami perubahan - perubahan dalam aspek kognitif, emosi, sosial, dan moral, di antara masa anak-anak menuju masa dewasa sehingga dibutuhkan suatu kendali dari sekitar agar terarah dengan baik. Terutama pada masa modern sekarang, pertumbuhan globalisasi yang sangat cepat sehingga memungkinkan budaya luar untuk masuk ke dalam Negara Indonesia dan permasalahan 
yang ditakuti adalah adanya pergantian budaya di dalamnya sehingga menyebabkan budaya asli luntur bahkan sampai beberapa remaja tidak mengenalinya. Seperti yang tengah booming saat ini adalah budaya Korea. Banyak remaja Indonesia yang menyukai budaya Korea mulai dari model pakaian, musiknya hingga makanannya. Kebanyakan remaja Indonesia rata-rata mulai menyukai budaya Korea di rentan usia pendidikan SD sampai di jenjang perkuliahan yang dipengaruhi oleh lingkungan sekitarnya terutama teman dekatnya.

Remaja dalam pergaulan sosialnya dipengaruhi oleh keluarga, teman sebaya, dan masyarakat sekitar. Namun, teman sebaya memiliki peran penting karena merupakan teman sepermainan dan remaja sering melakukan aktivitasnya bersama dengan teman sebaya. Minat remaja juga dapat dipengaruhi oleh teman sebaya. Salah satunya adalah minat terhadap budaya K-pop yang merupakan budaya pop yang sedang booming saat ini. Minat yang sama antar teman sebaya dapat mendorong remaja untuk membentuk komunitas atau fandom yang didasarkan pada kesamaan minat salah satunya minat pada budaya Korea yang disebut dengan Korean Wave. Untuk penggemar yang menyukai Korean Wave khususnya dalam bidang musik disebut dengan Kpopers. Melalui komunitas atau fandom K-pop, solidaritas di antara para anggota akan meningkat. Hal ini dikarenakan adanya kesadaran sebagai satu kesatuan yang dilandaskan pada kesamaan minat.

Persebaran Korean Wave sangat cepat didukung oleh beberapa platform media yang semakin memudahkan penyebaran Korean Wave. Salah satunya internet. Para remaja saat ini yang disebut sebagai generasi milenial dengan mudah mendapatkan informasi termasuk informasi mengenai budaya Korea termasuk Mahasiswa Fakultas Ilmu Sosial Universitas Negeri Malang yang menjadi penggemar Kpop.

Dari budaya Korea sendiri kebanyakan yang disukai oleh Mahasiswa Fakultas Ilmu Sosial Universitas Negeri Malang yang menjadi penggemar K-pop adalah musik yang dibawakan oleh boygrup dan girlgrup. Dari kesukaan terhadap musik ini menyebabkan remaja tersebut membeli barang-barang yang berhubungan dengan budaya musik Korea tersebut seperti album CD, poster boygrup atau girlband, dan photocard. Akibatnya adalah mereka tidak dapat mengontrol pengeluaran yang mengarahkan kepada budaya konsumerisme. Menurut Baudrillard (dalam Martono, 2016: 90) masyarakat konsumsi terlahir akibat adanya gejala globalisasi yang semakin marak terjadi di seluruh bagian dunia yang diawali dengan paham kapitalisme sehingga paham kapitalisme ini memanfaatkan arus globalisasi untuk memperluas pasar mereka. Tanpa sadar remaja Indonesia mengalami suatu hegemoni budaya luar sehingga menyebabkan suatu perilaku konsumtif kian marak terjadi akibat kurangnya suatu pengetahuan mengenai dampak dari globalisasi tersebut, sedangkan Mahasiswa Fakultas Ilmu Sosial Universitas Negeri Malang dalam membeli barang-barang serba Korea karena keinginan atau hobi mereka. Alasan yang kedua adalah untuk investasi. Investasi sendiri di sini diartikan ketika membeli album CD yang langkah, photocard dan poster asli yang nantinya akan dijual kembali sehingga uang yang mereka keluarkan akan tergantikan. Menurut Martono (dalam Martono, 2016, 92) menyatakan bahwa setiap barang akan memiliki nilai tukar yaitu nilai ekonomis yang ada pada sebuah objek konsumsi yang minimal dapat ditukar dengan uang atau benda lain (barter). Setiap barang akan memiliki nilai jual meskipun barang tersebut adalah bekas. Mereka biasanya membeli barang-barang K-pop dalam jangka waktu selama 3 bulan Barang-barang itu berupa photocard, aksesoris, dan poster saja, sedangkan untuk album CD mereka menunggu artis yang mereka sukai mengeluarkan kembali. 
Mahasiswa Fakultas Ilmu Sosial Universitas Negeri Malang menggunakan uang tabungan dan uang hasil kerja mereka untuk membeli barang-barang Korea tersebut. Mereka akan menghabiskan uang sekitar 200 ribu hingga 350 ribu yang dikeluarkan. Namun, bagaimana pun perilaku ini merupakan kesenangan mereka yang harus mereka penuhi. Sebagaimana menurut Baudrillard (dalam Martono, 2016, 91), pada awalnya kebahagiaan yang dicita-citakan manusia memiliki arti dan fungsi ideologis yang dapat disimpulkan dari akibat-akibat yang besar dari maknanya. Baudrillard sendiri mengartikan bahwa sesungguhnya keinginan yang dimiliki oleh manusia memiliki sebuah fungsi dan sebagai patokan. Namun, untuk saat ini barang-barang Korea dibeli hanya untuk memenuhi kepuasan batin tanpa memiliki fungsi di dalamnya sehingga dimanfaatkan oleh kapitalis untuk mencari sebuah keuntungan dari booming-nya budaya Kpop saat ini.

\section{Dampak Ekonomi}

Perkembangan Kpop atau Korean Wave telah mengalami peningkatan secara signifikan di seluruh dunia sehingga memberikan dampak dalam berbagai aspek baik ekonomi, sosial, maupun budaya. Dalam aspek ekonomi perkembangan K-pop telah

mendorong sikap konsumtif bagi para penggemar Korea yang didasari oleh perkembangan globalisasi sehingga menimbulkan adanya kapitalisme.

Konsumtif yang dilakukan oleh penggemar $K$-pop dapat berupa pembelian $K$ popstuff yang meliputi album, photocard, baju, aksesoris, dan merchandise lainnya yang berhubungan dengan idol yang dikagumi oleh para penggemar K pop. Para penggemar Kpop melakukan perilaku konsumsi K-popstuff didasarkan pada keinginan bukan kebutuhan. Hal ini dijabarkan oleh Baudrillard dalam teori konsumerismenya yang menyatakan bahwa rasionalitas dalam memenuhi kebutuhan tidak lagi didasarkan pada pemenuhan kebutuhan tetapi lebih mengarah pada pemenuhan keinginan. Hasil penelitian menunjukkan bahwa Mahasiswa Fakultas Ilmu Sosial Universitas Negeri Malang yang menjadi penggemar K-pop. dalam membeli $K$-popstuff didasarkan pada hobi untuk mengoleksi $K$-popstuff dan sebagai investasi karena $K$-popstuff tersebut akan diperjualkan kembali. Keinginan pada penggemar Kрор khususnya Mahasiswa Fakultas Ilmu Sosial Universitas Negeri Malang didasarkan pada hasrat individu dalam pemenuhan sesuatu yang berupa kpopstuff baik album, photocard, baju, lighstick, maupun Kpopstuff lainnya.

Keinginan sering bertabrakan dengan kebutuhan karena kebutuhan lebih berorientasi pada nilai guna dan fungsi, sedangkan keinginan didasarkan pada hasrat individu. Kebutuhan (needs) harus menjadi prioritas daripada keinginan karena kebutuhan sifatnya harus segera terpenuhi. Berbeda dengan keinginan hanya berdasarkan pada simbol dari objek konsumsi. Berdasarkan penelitian, mahasiswa di Fakultas Ilmu Sosial yang menjadi penggemar K-pop memiliki strategi tersendiri dalam memenuhi keinginannya dalam membeli $K$-popstuff sehingga kebutuhan primer tidak sampai terhambat karena K-popstuff. Strategi tersebut dapat melalui sistem menabung sehingga tidak terjadi ketimpangan dalam pemenuhan kebutuhan antara primer dan sekunder.

Para penggemar Kpop yang melakukan konsumsi pada Kpopstuff dapat mengarahkan pada pemborosan. Hal ini dikarenakan biaya yang dikeluarkan untuk membeli Kpopstuff tergolong tinggi. Para penggemar Kpopstuff berupaya dengan berbagai cara agar mampu memenuhi keinginannya dalam mengoleksi $K$-popstuff. Para penggemar K-pop sadar akan sikap boros yang ditimbulkan melalui kegiatan membeli 
K-popstuff, tetapi bagi penggemar K-pop hal tersebut didasarkan pada hobi dan sebagai upaya mendukung idola yang mereka gemari.

Sikap konsumtif melibatkan hasrat dan menurut Piliang (dalam Martono, 2016), objek yang mampu memenuhi hasrat ialah objek hasrat yang timbul di bawah alam sadar individu dengan tujuan untuk mencari subtansi (pengganti) dari simbolsimbol yang dikonsumsi. Dalam hal ini, sebenarnya yang dikonsumsi oleh remaja penggemar Kрор pada mahasiswa Fakultas Ilmu Sosial Universitas Negeri Malang ialah tanda pada suatu objek. Objek menjadi penentu identitas melalui tanda yang diciptakan sehingga individu dalam memperoleh identitas, ia harus melakukan konsumsi barang untuk mendapatkan tanda tersebut. Hal ini jika dikaitkan dengan tujuan konsumsi tidak lagi didasarkan pada pemanfaatan nilai guna barang, namun lebih menekankan tanda- tanda yang dimasukkan produsen dalam barang konsumsi yang tidak disadari oleh para pengguna barang konsumsi (Wulandari, dkk., 2018). Dalam hal ini kebutuhan mengutamakan mengkonsumsi „tandae daripada nilai gunanya. Para penggemar Kpop khususnya di kalangan mahasiswa dalam memenuhi kebutuhan $K$-popstuff lebih berorientasi pada pemenuhan keinginan untuk medapatkan tanda , $K$ pop $^{\text {ee }}$ daripada pemenuhan kebutuhan. Tanda ini didasarkan pada idol $K$-pop yang digemari oleh penggemar K-pop sehingga melalui konsumsi Kpopstuff para penggemar merasa dekat dengan idol yang digemari.

Baudrillard (dalam Martono, 2016) menyatakan bahwa kemampuan konsumsi tiap individu berbeda. Hal ini didasarkan pada material dan status yang dimiliki individu. Individu yang memiliki material lebih umumnya akan melakukan konsumsi dalam cakupan lebih besar daripada individu yang memiliki material yang sedikit. Untuk memenuhi pemenuhan keinginan dalam hal membeli K-popstuff, para penggemar Kpop dapat menabung terlebih dahulu untuk membeli K-popstuff. D a la m membeli barang $K$-pop didasarkan pada ketersediaan material. Material yang digunakan berasal dari orang tua maupun dari hasil sendiri yang kemudian disisihkan sebagian.

Untuk pemenuhan kebutuhan pokok, berdasarkan hasil penelitian, para penggemar K-pop lebih memprioritaskan kebutuhan terlebih dahulu yang kemudian diikuti dengan pemenuhan keinginan. Pemenuhan keinginan atau hasrat akan dilakukan jika kebutuhan pokok telah terpenuhi. Karena kebutuhan pokok yang menjadi utama dan harus segera terpenuhi.

\section{Dampak Budaya}

Saat ini Budaya K-pop sudah menyebar ke dalam masyarakat Indonesia terutama di kalangan remaja. Budaya K-pop tidak hanya ke arah music. Contohnya seperti Kuliner khas Korea yang menjalar di negeri ini dengan mudah ditemui di berbagai daerah di Indonesia. Ada pula brand dari Korea seperti make up yang saat ini sangat popular, pakaian ala-ala selebriti Korea juga sudah mulai digemari oleh masyarakat di kalangan remaja. Dengan adanya budaya asing yang masuk, secara perlahan akan menggeser Budaya Indonesia. Remaja masa kini lebih menggemari Budaya K-pop daripada budayanya sendiri. Akibat dari masuknya Budaya K-pop akan mendorong masyarakat menjadi masyarakat konsumeris. Masyarakat Konsumeris adalah masyarakat yang menciptakan nilai-nilai yang berlimpah ruah melalui barang-barang

konsumeris dan menjadikan konsumsi sebagai aktifitas kehidupan (Pawanti, 2013). Disadari atau tidak, masyarakat terutama remaja yang terpengaruh oleh Budaya Kрор kecenderungan menjadi masyarakat konsumeris. Hal ini ditandai dengan mereka yang mengkoleksi barang-barang yang berbau Kpop atau yang biasa disebut dengan Kpopstuff seperti Aksesoris, Majalah, Poster, skin care, CD Album dan masih banyak 
lagi. Remaja yang terpengaruh dengan Budaya $K$-pop juga dapat dilihat dengan cara berpakaian dan gaya rambut atau yang bisa disebut sebagai Korean style.

Menurut pendapat Baudrillard, yang dikonsumsi oleh masyarakat konsumeris bukanlah kegunaan dari suatu produk, melainkan citra atau pesan yang disampaikan dari suatu produk (Pawanti, 2013). Sebagai contoh remaja yang menggemari Budaya $K$-pop membeli produk skin care dengan brand dari Korea yang biasa digunakan oleh artis Korea. Mereka ingin membeli produk tersebut bukan hanya untuk memenuhi kebutuhan, melainkan melalui cara itu produk skin care tersebut ditnawarkan sebuah citra kemewahan dengan harga terjangkau. Selain itu, Baudrillard berpendapat bahwa setiap individu dalam masyarakat konsumeris memiliki keinginan untuk terus mengkonsumsi produk-produk yang dianggap akan menaikan status sosialnya (Pawanti, 2013). Dalam penelitian ini hasil yang kami dapat bahwa masyarakat di kalangan remaja yang terpengaruh oleh Budaya K-pop lebih update dan mengikuti perkembangan Budaya K-pop daripada Budaya mereka sendiri. Mereka lebih mengetahui produk atau Brand yang diproduksi oleh Negara Korea dibandingkan dengan produk dalam negerinya sendiri.

\section{Dampak Sosial}

Di tengah masifnya budaya Korea saat ini di Indonesia memiliki dampak sosial juga terhadap para remaja dan pemudanya khususnya bagi mahasiswa Fakultas ilmu Sosial Universitas Negeri Malang. Kebanyakan dari mereka yang menyukai budaya Korea saat berbicara dengan orang yang memiliki kesamaan kegemaran akan menggunakan embel-embel bahasa Korea ketika melakukan interaksi seperti katakata "ommo" "daebak" "jinja". Mereka tengah mengalami gejala imitasi yang sedang melakukan sebuah peniruan tetapi tidak secara keseluruhan. Mereka hanya ingin menunjukkan eksistensi mereka kepada khalayak umum. Proses imitasi ini terjadi akibat dari proses pencarian identitas mereka. Sedangkan bagi penggemar budaya Korea yang menyatakan bahwa mereka tidak menggunakan embel-embel bahasa Korea dalam percakapan mereka karena mereka merupakan orang Indonesia asli.

Baudrillard memandang objek konsumsi sebagai sesuatu "yang diorganisisasi oleh tatanan produksi" atau dalam artian lain, kenyataannya kebutuhan dam konsumsi adalah perluasan kekuasaan produktif yang diorganisasi sehingga ehingga secara tidak langsung menyebabkan sebuah kolonialisasi baru berbentuk budaya. Dalam kegiatan kolonialisasi ini memiliki dampak adanya status sosial. Hal ini menimbulkan suatu perubahan sosial di masyarakat khususnya bagi mahasiswa Fakultas Ilmu Sosial Universitas Negeri Malang. Perubahan tersebut ditunjukkan dengan kemampuan para mahasiswa Fakultas Ilmu Sosial Universitas Negeri Malang dalam menunjukkan status sosial mereka dengan membeli $K$-popstuff yang memiliki biaya tinggi. Akibatnya, para pencinta Kpop dikalangan mahasiswa FIS UM akan mengakui status sosialnya yang tergolong kelas atas. Meskipun begitu, para pecinta budaya Korea ini masih bisa bergaul dan berinteraksi dengan orang-orang yang tidak memiliki kesukaan atau kegemaran yang sama sebab pada hakikatnya manusia membutuhkan manusia lain untuk hidup dan memenuhi kebutuhannya sehingga menuntut seseorang untuk berinteraksi dengan lingkungan sekitar. Kegiatan ini sendiri tidak menjauhkan mereka dari lingkungannya melainkan mengubah lingkungan sosial mereka menjadi lebih kompleks sebab mereka akan terpengaruh melakukan kegiatan konsumtif melalui lingkungan sosial mereka yang menjadi dominan pecinta budaya Korea dan melalui iklan-iklan yang dipasang di sosial media. Mereka akan tanpa sadar membeli barang-barang tersebut karena rasa ingin memilikinya saja dan menunjukkan bahwa mereka adalah penggemar sejatinya. Hal ini juga didukung oleh peran orang tua. 
Kebanyakan dari penggemar K-pop menyatakan bahwa orang tua mereka mendukung akan adanya kegiatan tersebut. Meskipun begitu, orang tua mereka masih memberi batasan terhadap kegiatan mereka. Mereka akan dinasehati apabila mulai mencapai suatu tingkat keborosan yang tinggi.

Sebenarnya bila dipahami konsumerisme menyebakan suatu kesenjangan sosial di masyarakat. Ini dikarenakan setiap orang akan memiliki kemampuan belanja yang berbeda-beda. Hal ini ditandai dengan masih banyak penyuka budaya Korea yang mendapatkan barang-barang Korea dari hasil pemberian teman. Bahkan mereka menikmati musia Korea dengan tidak membeli sebuah album CD melainkan melalui internet. Dapat dilihat bahwa setiap orang tidak memiliki kesempatan yang sama untuk menikmati barang-barang yang diproduksi oleh kaum kapitalis. Muncullah sebuah diskriminasi pada makna di saat hanya beberapa orang yang mampu mencapai logika otonom, rasional, dan unsur-unsur lingkungan hidup.

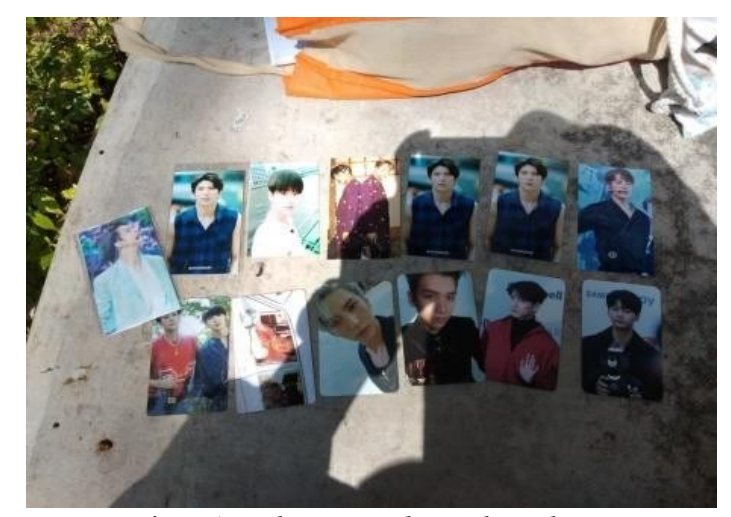

Gambar 1. Photocard Boyband VIXX

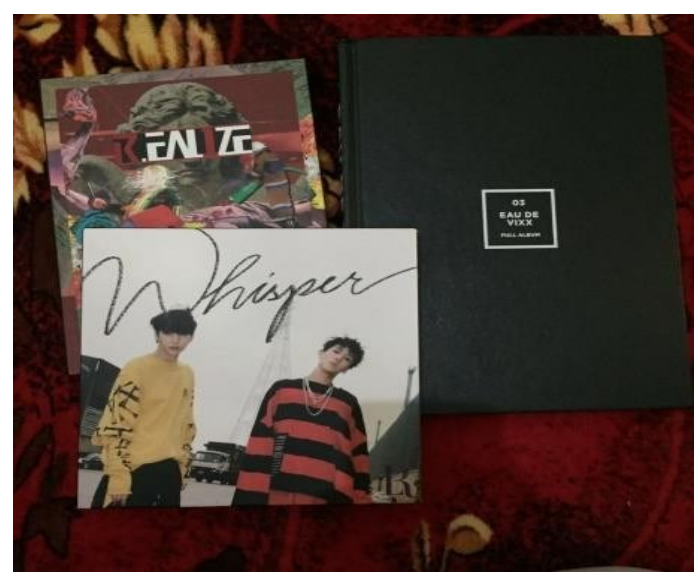

Gambar 2. Album Boyband VIXX 




Gambar 3. Pakaian Boyband VIXX

\section{SIMPULAN}

Remaja merupakan masa pencarian jati diri dan memiliki keinginan tahuan yang tinggi. Termasuk budaya K-pop yang saat ini massf di kalangan remaja, khususnya mahasiswa. Budaya kpop ini dapat mendorong sikap konsumtif dikalangan remaja karena adanya fenomena belanja K-popstuff. Sikap konsumtif ini merupakan dampak dari terbentuk dari adanya perkembangan globalisasi.

Dampak dari konsumerisme ini mencakup berbagai bidang, antara lain ekonomi, sosial, dan budaya. Dalam aspek ekonomi, konsumerisme menyebabkan adanya sikap pemborosan serta perubahan nilai guna suatu barang yang awal pembelian didasarkan pada kebutuhan (needs), tetapi dengan adanya fenomena konsumerisme menyebabkan pembelian barang konsumsi lebih mengutamakan keinginan dan hasrat untuk memiliki produk tersebut. Dalam aspek budaya, budaya K-pop menyebabkan remaja mulai meninggalkan budaya Indonesia. Mereka lebih mengetahui budaya K-pop dibandingkan dengan budayanya sendiri. Dalam hal berpaikan mereka lebih mengikuti Korean Style dan lebih memilih produk kecantikan dengan brand Korea. Dari dampak sosial kegiatan konsumerisme ini memicu adanya kesenjangan sosial di masyarakat sebab terdapat beberang orang yang tidak bisa membeli barang-barang Korea dan hanya mengandalkan pemberian teman serta via internet. Selain itu, pada interaksi dengan lingkungan sekitar tidak berdampak apapun ketika suatu lingkungan tetap mengontrol dan mendukungnya.

\section{DAFTAR PUSTAKA}

Ilham, M. (2017). Representasi budaya populer meme comic Indonesia (analisis semiotika meme dalam fanpage meme comic Indonesia. (Doctoral dissertation). Diunduh dari http://repository.unhas.ac.id. Diakses 1 Mei 2019

Martono, N. (2016). Sosiologi perubahan sosial. Depok, Indonesia: PT.Reja Grafindo Persada.

Pawanti, M. H.(2013). Masyarakat konsumeris menurut konsep pemikiran Jean Baudrillard. Diunduh dari http://lib.ui.ac.id), diakses 13 Maret 2013

Sholihah, N dan Sudrajat, A. (2019). Dampak modernitas k-pop pada gaya hidup siswi di sekolah berbasis pesantren (studi MTS Ali Maksum pondok pesantren Krapyak Yogyakarta). Jurnal Sosiologi Reflektif, 13(1), 47-59. 
Wulandari, S. (2018). Perilaku konsumtif peserta didik peserta didik penggemar k-pop di SMA Negeri 4 Surakarta. SOSIALITAS; Jurnal Ilmiah Pend. Sos Ant, $8(1)$. 